Prácticas sonoras de las poblaciones aborígenes de Costa Rica y su influencia en la música académica costarricense de los siglos XX y XXI: hacia una historiografía de imaginarios sonoros (1986-2016)

\author{
Sonoric Practices of the Indigenous People from \\ Costa Rica and their influence in the XX and XXI Century's \\ Costa Rican Academic Music: to a Historiography of the \\ Sonoric Imagery (1986-2016)
}

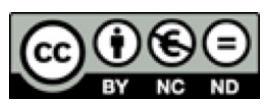

Esta obra está bajo una licencia Creative Commons Reconocimiento-No comercial-Sin Obra Derivada 


\title{
Prácticas sonoras de las poblaciones aborígenes de Costa Rica y su influencia en la música académica costarricense de los siglos XX y XXI: hacia una historiografía de imaginarios sonoros (1986-2016)
}

\author{
Sonoric Practices of the Indigenous People from \\ Costa Rica and their influence in the XX and XXI Century's \\ Costa Rican Academic Music: to a Historiography of the \\ Sonoric Imagery (1986-2016) \\ Leonardo Gell Fernández-Cueto ${ }^{1}$ \\ Universidad de Costa Rica \\ Costa Rica
}

Recibido: 29 de agosto del 2018 Aprobado: 26 de noviembre del 2018

\begin{abstract}
Resumen
Este artículo historiográfico pretende exponer cómo ha sido contada la historia de las prácticas sonoras de las comunidades aborígenes costarricenses, en el período comprendido entre 1986 y 2016. Las preguntas que originaron el estudio buscan desentrañar, además, la influencia que las culturas primigenias han ejercido en la creación académica contemporánea, en tanto los compositores costarricenses han tomado insumos de sus tradiciones socioculturales para concebir obras propias.
\end{abstract}

Palabras clave: historiografía, comunidades aborígenes, prácticas sonoras, música contemporánea

1 Docente y Coordinador de la Sección de Piano de la Escuela de Artes Musicales de la Universidad de Costa Rica. Máster en Música con énfasis en Piano por Universidad de Costa Rica. Correo electrónico: leonardo.gell_f@ucr.ac.cr 


\begin{abstract}
This historiographic article intends to expose how the history of the sound practices of the Costa Rican aboriginal communities have been told, in the period between 1986 and 2016. The questions that originated this study seek to unravel, in addition, the influence that the primitive cultures have exerted in contemporary academic creation, while Costa Rican composers have taken inputs from their sociocultural traditions to conceive their own works.
\end{abstract}

Keywords: historiography, indigenous communities, sound practices, contemporary music. 
Prácticas sonoras de las poblaciones aborígenes de Costa Rica

y su influencia en la música académica costarricense de los siglos XX y XXI:

hacia una historiografía de imaginarios sonoros (1986-2016)

\section{Introducción}

Durante el siglo XX, las temáticas de lo indígena, lo autóctono y lo nacional se convirtieron en herramientas útiles para la creación artística, en ese afán por "recuperar" la identidad nacional, aquello que "nos pertenece" y "nos permite ser" de un lugar. Como prácticas se hicieron recurrentes casi siempre de la mano de los movimientos nacionalistas que afloraron, paralelamente y tras las vanguardias. Este fenómeno tiene, en Latinoamérica, consecuencias profundas, en tanto deviene de un proceso violento de colonización, que desde finales del siglo XV atacó a nuestras poblaciones originarias. Bien lo describe Walter Mignolo en su libro La idea de América Latina (2007) cuando se refiere a la "herida colonial", esa a la que aún hoy intentamos encontrarle respuestas y soluciones de cara al futuro como región.

Costa Rica, si bien no cuenta con una población mayoritariamente aborigen, dispone de algunos asentamientos que, en la actualidad, dialogan con la sociedad resultante del largo proceso de colonización occidental. De acuerdo con José Carballo (2008), en su informe "Los grupos indígenas costarricenses", existen en el país ocho grupos socioculturales divididos en Cabécares, Bribris, Ngäbe, Térrabas, Borucas, Huetares, Malekus y Chorotegas. Estos coexisten en veinticuatro territorios y hablan seis idiomas propios. Carballo añade que el censo realizado en el año 2000 por el Instituto Nacional de Estadística y Censo (INEC) arrojó que en el territorio nacional habitan 63876 personas aborígenes, las cuales representan el 1.7\% de la población costarricense (pp. 1-2).

Durante varias décadas, un grupo de investigadores se ha dado a la tarea de acercarse a esas poblaciones para conocer y estudiar sus comportamientos, dejando constancia de ello en una gran cantidad de publicaciones y otros soportes de información. Para el presente estudio serán de utilidad aquellos textos que permitan construir una historiografía acerca del cómo ha sido abordado el tema de las prácticas sonoras de las culturas aborígenes de Costa Rica y la manera en que estas prácticas han influenciado la música académica producida en el país, durante el siglo XX y lo que va del XXI. La falta de un acercamiento similar hasta la fecha constituye el primer criterio de pertinencia para abordar un recuento historiográfico sobre el objeto de estudio. Pero, también lo es el hecho de hurgar en aquellos aspectos de dichas culturas que han sido asimilados por los creadores contemporáneos, en su aspiración por "reconstruir" el pasado que de alguna forma "les pertenece".

Cuando los compositores acuden a las poblaciones aborígenes captan aquellos elementos que son de su interés mediante una imagen sonora. Esta responde al constructo auditivo que le proporcionan los instrumentos de su cultura formativa, el "oído foráneo" al que se refiere Laura Cervantes (1995). Todo ello, con el objetivo de plasmar dichos elementos y -en el mejor de los casos- recrearlos, al hacer uso de un sistema de notación musical que no comulga con el origen de esas prácticas sonoras. Este fenómeno ha sido 
ampliamente estudiado, desde diferentes disciplinas, tanto de las Ciencias Sociales como desde las Artes. El conflicto radica, precisamente, en que el "nosotros" no logra despojarse de las estructuras de análisis aprehendidas para juzgar al "otro". De ahí que, como apunta Daniel Montero (2016), "la percepción estética occidental, como identidad cultural fija, se presenta como paradigma para el estudio de otras formas estéticas que se asumen como alteridades de tal identidad" (p. 122). En el caso que nos ocupa, esta actitud evidencia que los compositores ejercen el principio de otredad y manifiestan cierta necesidad de empatía con ese "otro" al que se acercan, para generar un nuevo discurso con insumos de diversa procedencia, espacialidad y temporalidad.

Sin embargo, el tema de la percepción en sí merece un análisis más profundo que no es objetivo del presente trabajo. No obstante, el lector debe saber que un proceso de asimilación cultural -como el que aquí abordamos- no puede ser valorado de otra forma que no sea a partir de la reinvención del imaginario sonoro. Susan Campos (2014) asegura que: "ya no se trata solo con la 'expectación de otredad' del análisis 'desoccidentalista', sino con la 'otredad propia' producto de 'etnografías imaginarias' que son 'arqueologías de sí' en el presente" (p. 42). De ahí que ponderemos en esta investigación la producción contemporánea costarricense con influencia explícita de las culturas aborígenes del país.

En Costa Rica, las poblaciones originarias corren el riesgo de extinguirse, tal y como lo afirma Jorge Luis Acevedo (citado por Campos, 2014). Quizás, sea esta una de las urgencias principales que han obligado a los creadores costarricenses a dirigirse hacia estas culturas. No en balde, algunos investigadores han alertado sobre esta problemática, entre ellos, Carlos Paz (2011), quien expone su preocupación respecto a la continuidad de las tradiciones orales de la comunidad bribri, a través de un estudio de campo realizado en las poblaciones de Kéköldi, Suretka, Amubri y Cachabrien. Su investigación arrojó que los jóvenes entre dieciséis y treinta años se sienten más identificados con las prácticas musicales impuestas por los medios de comunicación actuales, no así a aprender y ejercitar los cantos propios de su comunidad. Este tema fue abordado anteriormente por María Clara Vargas (2004), Rodrigo Salazar (2002), Carlos Borge y Victoria Villalobos (1994) y Cervantes (1991a, 1992, 1995 y 2003), lo que supone un fenómeno extendido a lo largo de varias décadas y que pudiera desencadenar en una extinción total de estas prácticas en un futuro a mediano y largo plazo. Con relación a la interacción que se ha producido durante la segunda mitad del siglo XX entre el pueblo bribri y la cultura occidental, Daniel Rojas asegura que: 
Prácticas sonoras de las poblaciones aborígenes de Costa Rica

y su influencia en la música académica costarricense de los siglos XX y XXI:

hacia una historiografía de imaginarios sonoros (1986-2016)

En este proceso de creación y desarrollo, de continuo desenvolvimiento de los pueblos como creadores constantes de sus tradiciones e identidades, todo lo nuevo que aparecía ante sus ojos y ante su propia experiencia ha implicado, a su vez, una readecuación de sus formas de vida, de sus formas de ver el mundo y de sus formas de identificarse (2002, p. 17).

Por lo anterior, se espera que el corpus consultado ayude a responder algunas preguntas de investigación: ¿cómo ha sido contada la historia de las prácticas sonoras de los pueblos originarios costarricenses en el período de estudio?, ¿cuáles son los elementos o prácticas de las culturas primigenias que ponderan en sus obras los creadores contemporáneos costarricenses? y ¿qué tecnologías o combinaciones instrumentales emplean, con mayor frecuencia, para recrear dichas prácticas? Como lo requiere una historiografía, serán comentadas las publicaciones encontradas, a partir de las cuales se establecerán tendencias según las características de estas. Para su elaboración hemos considerado aquellas publicaciones comprendidas entre 1986 y 2016, período en el cual se encontraron libros, artículos y ensayos académicos, así como otros textos dedicados al objeto de estudio: notas discográficas y entradas de blogs. Juliana Pérez asegura que Luiz Heitor Corrêa:

es el primero que considera importante, además de los textos publicados, otros medios de difusión del conocimiento como las instituciones de enseñanza y los organismos que han girado en torno a la musicología y, además, introduce en su balance productos de la investigación histórica diferentes de los textos de síntesis, como son la edición de partituras, los catálogos de archivo y las grabaciones (Pérez, 2007, p. 7).

Basados en este argumento, consideramos que son de gran relevancia los textos que acompañan a algunas producciones discográficas publicadas en el período de estudio. La grabación fonográfica en cualquiera de sus soportes existentes (LP, casete, CD o plataformas digitales), generalmente, es acompañada de comentarios que aluden al concepto que maneja cada proyecto, por lo tanto, podemos afirmar que se ha convertido en un soporte alternativo para la generación de conocimiento. Como se apreciará más adelante, estos textos fueron concebidos por autores que recurrieron a este y otros medios para plasmar su expertise respecto al tema en cuestión.

\section{Prácticas sonoras (¿musicales?) de las poblaciones originarias de Costa Rica}

Para conocer cómo ha sido contada la historia de las prácticas sonoras de estas comunidades -primera interrogante de la investigación-, nos dedicaremos a exponer el contenido de las publicaciones realizadas en torno al tema de estudio. Esto nos permitirá dilucidar las perspectivas desde las cuales se han analizado estos comportamientos y el grado de 
profundidad alcanzado. Como punto de partida consideramos el libro Música en las reservas indígenas de Costa Rica de Acevedo (1986), pues constituye uno de los aportes más significativos en los campos de la investigación histórica y etnográfica realizados en el país. Su publicación revela una búsqueda exhaustiva de documentos periódicos y académicos, a partir de los cuales realiza un recorrido por los principales asentamientos aborígenes en suelo costarricense. El propio Acevedo mantuvo un contacto directo con estas comunidades, por cuanto los datos aportados alcanzan una gran relevancia, tanto por el volumen de información como por el contenido. El autor dedica especial atención a describir los cantos e instrumentos empleados, a partir de la compilación de crónicas que desde el siglo XVI fueron comentando las prácticas sonoras de estas poblaciones.

Observamos cómo los cronistas citados en el libro y el propio Acevedo hacen constante mención a los métodos occidentales de organización musical, para dar respuesta o encontrar analogías entre los cantos aborígenes y los modelos teóricos establecidos por la música europea. Precisamente, esta es otra contribución del libro, en tanto ofrece una gran cantidad de partituras con las escalas precolombinas que producen las ocarinas resguardadas en las colecciones del Museo del Instituto Nacional de Seguros (INS) y el Museo Nacional; así como de los cantos aborígenes. Para la época, este esfuerzo podía tener, al menos, dos implicaciones futuras: en primer término, la utilización de dichos materiales como fuente para posteriores investigaciones, en segundo lugar, tomar estas melodías como punto de partida para la elaboración de obras propias por parte de compositores contemporáneos. Esta constante traducción del lenguaje sonoro autóctono a la notación y presupuestos teóricos de la música occidental fue abordada por Acevedo, incluso, al referirse a los aspectos distintivos de los diferentes cantos aborígenes. Más allá de la dicotomía que esto puede acarrear, si lo analizamos desde una perspectiva descolonizadora, lo importante es el hecho de poder acercar a nuestra cultura esos elementos.

En 1988, Carmen Rojas publicó "Descripción y análisis de la fiesta de los diablitos de boruca", artículo donde detalla las características de dicha celebración y menciona escasamente algunos de los instrumentos utilizados y el momento en el que estos intervienen dentro de la práctica musical de la festividad. Por su parte, en 1991, Enrique Margery publicó su artículo "Notas en torno a la forma y contenidos de una muestra de cantos de cuna cabécares", en el cual realiza un análisis lingüístico detallado de los textos de dos cantos de cuna cabécares. El autor reconoce que, al carecer de bases musicológicas que le permitan profundizar en el tema, se limitó a hacer comentarios muy generales desde el punto de vista musical (p. 132). 
Prácticas sonoras de las poblaciones aborígenes de Costa Rica

y su influencia en la música académica costarricense de los siglos XX y XXI:

hacia una historiografía de imaginarios sonoros (1986-2016)

En 1990, Laura Cervantes realizó su tesis de maestría en la Universidad Estatal de Nueva York en Albany, Estados Unidos, titulada "Sulàr: Playing for the Dead [Sulàr: Jugando por los muertos]". En ella, la autora realiza un estudio profundo acerca de la comunidad bribri y sus rituales funerarios, a la vez, hace hincapié en aspectos socioculturales, específicamente, de índole lingüístico y musical. Entre sus aportes al aspecto sonoro se encuentran la descripción de dieciocho cantos y la estructura, así como su clasificación genérica según la temática en la cual son utilizados. Parte de su investigación fue utilizada en trabajos suyos posteriores, los cuales se comentan a continuación.

Entre 1991 y 1995, Cervantes publicó una serie de artículos que deben estudiarse en su conjunto, ya que se complementan entre sí a partir de los datos que aportan: "Los géneros musicales bribris: aspectos sociolingüísticos de su ejecución" (1991a), "Observaciones etnomusicológicas acerca de tres cantos de cuna cabécares" (1991b), "La temática de los cantos fúnebres bribris" (1991c), "La función social de la música en el ritual fúnebre bribri" (1992) e "Información básica acerca de la música tradicional indígena de Costa Rica" (1995). Los cinco textos continúan la línea descriptiva, con el objetivo de contextualizar al lector en las características de los fenómenos y comportamientos socioculturales, prácticas religiosas, cantos e instrumentos ejecutados por estas poblaciones. Asimismo, sus artículos enfatizan en el análisis lingüístico que, por la naturaleza sonora de su producción, está relacionado con el aspecto musical, especialmente, con el habla ritual:

[que] es una variedad lingüística en la que el texto solo existe cantado, la música no existe independientemente del texto, y el tipo de discurso solo existe con ese texto y esa música. Ese es el carácter de la lengua general del universo, el resultado de una combinación única y exclusiva (Cervantes, 1991c, p. 84).

Los datos propiamente musicales que ofrece la autora, a partir de la percepción de los cantos estudiados, hacen referencia a aspectos básicos como la instrumentación, colocación de la voz, tesituras vocales, relaciones interválicas, dirección de los movimientos melódicos, cantidad de sonidos en una misma escala o velocidad de los cantos, por solo citar algunos. Sobre este particular, el aporte más significativo es, quizás, la clasificación y caracterización de los distintos géneros musicales, según la temática o práctica en que eran ejecutados los cantos. Al igual que lo hizo Acevedo (1986), Cervantes (1991b) brinda la notación musical (partitura) de tres cantos de cuna de origen cabécar, a partir de los cuales realiza un análisis de estructura musical y ofrece datos paramusicales². Mientras que, en (1991a) describe la relación de complementariedad que se establece entre mujeres y hombres durante la ejecución sonora. Este artículo evidencia que las primeras solo cantan en bribri, en tanto los segundos pueden

2 En Cervantes (1990) aparece también la notación musical en partitura del canto \# 10 (p. 120). 
hacerlo en bribri y téribe macarrónico, como también ejecutar otros instrumentos en la misma intervención. De igual forma, hace referencia a la participación de los roles femeninos y masculinos en las prácticas danzarias de esta comunidad.

Por otro lado, Cervantes (1992) realiza una exhaustiva descripción del proceso ceremonial funerario del pueblo bribri, cuya fase final es la de mayor afluencia de participantes en torno a una práctica ritual; realizan ejecuciones a nivel grupal y, a su vez, constituye el único momento donde son invocados públicamente seres sobrenaturales, propios de su visión de mundo (p. 264). Para una mayor comprensión, la autora ofrece tres tablas donde pueden apreciarse las características específicas de ejecución musical según los géneros tradicionales de esta comunidad. Como parte de su descripción, incluye los diferentes tipos de danza (lineal y circular), acotando acerca de la interacción que se establece entre danzantes, cantores, sus asistentes y quienes ejecutaban los instrumentos acompañantes. Otro aspecto destacable en este artículo es que Cervantes, apoyada en el Sistema Internacional de Notación Kinetography Laban, aporta tres figuras que ejemplifican los pasos de hombres y mujeres en cada una de estas danzas (pp. 254-256).

Por su parte, Cervantes (1995) formaliza una descripción de algunos de los instrumentos cordófonos, membranófonos, idiófonos y aerófonos que utilizan estas poblaciones, al hacer énfasis en los materiales de construcción, características físicas y momentos en los que se utilizan. Este trabajo considera las prácticas sonoras de los bribris, cabécares, guaimíes, bocotás, borucas, térrabas y guatusos. En sentido general, la autora asegura que su investigación se centra en "los factores culturales que determinan la producción sonora y no del producto en sí" (1991a, p. 243). Por ello, advierte que sus textos contienen información preliminar que debe ser profundizada, en tanto le confiere un énfasis especial a aquellas perspectivas que puedan hacer referencia a la relación música-mito-ritual o a "la música como un indicador del cambio cultural” (1991a, p. 253).

El libro Instrumentos musicales del folclor costarricense de Salazar (1992) incluye artefactos utilizados por poblaciones precolombinas y algunas que aún conservan sus prácticas sonoras, a través de un instrumental propio. El autor se apoya en tres disciplinas para emprender su investigación: etnomusicología, organología y organografía, a partir de las cuales ofrece información acerca de los orígenes étnicos, función social, aspectos constructivos, características decorativas, clasificación y formas de ejecución (incluyendo, ocasionalmente, algunas combinaciones rítmicas y melodías en notación occidental). Salazar advierte que algunas de estas comunidades conservan sus expresiones sonoras de forma intacta (cabécares, bribris, guatusos y guaimíes), no así los borucas, donde: 
Prácticas sonoras de las poblaciones aborígenes de Costa Rica

y su influencia en la música académica costarricense de los siglos XX y XXI:

hacia una historiografía de imaginarios sonoros (1986-2016)

se nota una fuerte influencia europea (española) y africana que llegó a ellos en tiempos de la colonia por parte de los "chiricanos" (panameños); entre las manifestaciones de esta influencia se puede citar la utilización del violín, la caja, la guitarra, además de los ritmos como el floreo, paseo, punto, son y cumbia chiricana (Salazar, 1992, p. 17).

Con esta aseveración, puede apreciarse cómo una de las comunidades estudiadas interactúa con instrumentos propios de otras poblaciones foráneas con las cuales compartió espacio. Por tanto, no es extraño que aprecie y se apropie de algunas de sus tradiciones socioculturales para incorporarlas a sus prácticas cotidianas.

En 1996 fue publicado el libro Historia antigua de Costa Rica: surgimiento y caracterización de la primera civilización costarricense de Oscar Fonseca. Aunque el texto profundiza en los comportamientos de los primeros pobladores del territorio nacional, al hurgar en formas de producción, construcción político-social, entre otras, encontramos escasos párrafos referentes a las manifestaciones sonoras de las comunidades primigenias. Esto, apenas para mencionar algunos grupos de instrumentos y su interacción con el canto humano "en las fiestas y bailes, como parte de su vida cotidiana compleja, y cargada de sentido social, estético e ideológico" (p. 207).

Para el año 2002, Rodrigo Salazar publicó su libro El indígena costarricense: una visión etnográfica, en cuyo apartado Arte y recreación ofrece datos comparativos entre varias comunidades aborígenes, a partir de sus prácticas sonoras. En 1992, el autor aseguró que los borucas habían incorporado influencias foráneas (española y africana, a través del contacto con los aborígenes panameños) en sus manifestaciones sonoras cotidianas. Sin embargo, en la presente publicación también incluyó en ese pequeño grupo a los térrabas. Su ejercicio comparativo se sustenta en los cantos ejecutados por dichas comunidadesa las que se suman cabécares, bribris, guaimíes y guatusos-, dedicados a: trabajo, entretenimiento, arrullo, pubertad, iniciación, cacería, ritos funerarios, curación, entre otros. El autor hace referencia a la instrumentación que acompaña a la voz (en los casos en que aplica); al uso de la escala pentatónica descendente en el motivo melódico de algunos de los cantos, versus la repetición constante de un solo sonido (según la población ejecutante); entre otros aspectos de interés. Posteriormente, describe algunas de las danzas ceremoniales practicadas en torno a cantos propios de dichos fenómenos socioculturales, al tiempo que describe varios de los instrumentos utilizados por estas comunidades, estudio que tiene su génesis en su publicación de 1992. Al igual que otros especialistas en el tema, Salazar se apoya en el contacto directo con los aborígenes y algunos de ellos fueron sus propios informantes. 
En 2003, Cervantes realizó su tesis doctoral en la Universidad de Texas en Austin, Estados Unidos, titulada: Sounds like music: ritual speech events among the Bribri Indians of Costa Rica [Sonidos como música: eventos de habla ritual entre los indios bribri de Costa Rica]. El tercer capítulo de la investigación está dedicado a estudiar el fenómeno musical de esta comunidad, cuyo título es: Bribri verbal art and music [Música y arte verbal bribri]. Al igual que en sus estudios anteriores, Cervantes se acerca al fenómeno musical a partir del resultado sonoro del discurso verbal, como parte de un contexto de interacción sociocultural entre los aborígenes bribris. Dentro de las características de algunos cantos, la autora destaca diferencias entre las secciones cantadas y los recitativos, en su relación con el contenido verbal. De igual modo, describe aspectos musicales referentes al rango de las voces que ejecutan los cantos, el empleo ocasional del vibrato o el falsetto, el tempo, el ritmo, entre otros detalles. Además, aporta fragmentos de partitura con la notación occidental de varios cantos.

En 2004, María Clara Vargas participó en el primero de tres volúmenes en formato de libro: Costa Rica en el siglo XX, como autora del capítulo titulado La música. Vargas realizó un recuento histórico en torno al ejercicio musical en el país, durante la pasada centuria, dentro del cual se refirió muy sucintamente a las comunidades aborígenes, asegurando que "el grupo que conserva mayor cantidad de manifestaciones musicales con carácter original es el de los bribri, al través [sic] de sus cantos" (p. 296). El resto de referencias hechas por la autora aluden al habla ritual utilizada en las ceremonias, a algunos de los cantos, bailes y personas que los ejecutaban dentro de la población bribri. Estos elementos descriptivos fueron expuestos y profundizados en textos citados aquí con anterioridad.

Hasta el año 2010 es que encontramos un primer artículo con características historiográficas. Se trata de "Algunas miradas sobre la música indígena costarricense" de Carlos Paz, quien comenta cinco textos en formato de libro y revistas especializadas, publicados entre 1942 y 1995. Su objetivo se dirige hacia la búsqueda de publicaciones donde es tratado el tema de la música en las culturas primigenias. Es decir, aquellas que hacen referencia a este o que contuvieran transcripciones en notación occidental de los cantos y melodías propias de los aborígenes costarricenses. Este artículo alude a algunos textos fundamentales de la investigación histórica y etnomusicográfica realizada en el país, tales como La música en Costa Rica de Bernal Flores (1978), La música en Guanacaste (1980) y Música en las reservas indígenas de Costa Rica (1986), ambos de Acevedo. Paz se basa en la descripción de estas publicaciones, a manera de guía breve, para introducir a los lectores en cómo ha sido abordado el tema de la música, en dichas culturas. Este recuento historiográfico no es exhaustivo, por cuanto consideramos que pudo enriquecerse con otras fuentes producidas durante el período abordado (53 años), algunas de las cuales 
Prácticas sonoras de las poblaciones aborígenes de Costa Rica

y su influencia en la música académica costarricense de los siglos XX y XXI:

hacia una historiografía de imaginarios sonoros (1986-2016)

han sido incluidas en la presente investigación. No obstante, de forma expresa dejó abierto el campo a futuros estudios que se interesen en incrementar los acercamientos desde otras perspectivas.

En 2011, Jeffrey Peytrequín publicó el artículo "Identidad y prácticas rituales funerarias en Costa Rica, 300-800 d.C. Una interpretación", en el cual intenta dar explicaciones respecto al rompimiento de objetos de cerámica durante los rituales funerarios de la Fase Curridabat. En su disertación, dedica una brevísima referencia a las prácticas sonoras y dancísticas de este grupo social, en tanto acciones "complementarias a los enterramientos" (p. 256).

Las publicaciones comentadas hasta el momento se han dedicado a construir una historia con un contenido eminentemente descriptivo, tanto de las prácticas socioculturales como de la inserción en estas de los cantos e instrumentos propios. Pero, también, se han dedicado al análisis lingüístico de los textos; a la transcripción en notación occidental de algunos de los cantos y, por último, a registrar una breve historiografía, publicación que tomamos como un hecho aislado hasta el momento. Podemos afirmar, entonces, que la tendencia hasta el año 2011 fue la de continuar describiendo los aspectos propios de estas poblaciones.

\section{Música-mito-ritual: el simbolismo ancestral en la creación académica costarricense}

Como se comentó anteriormente, el hecho de que algunos investigadores se dedicaran a transcribir en notación occidental los cantos de las comunidades aborígenes podía tener, como implicación futura, que compositores académicos los tomaran como materia prima para concebir obras propias. Cabe aquí la posibilidad de utilizar el concepto de poiesis, que nos conduce a pensar en la apropiación de insumos que hacen los creadores para concebir una obra de arte original. Este es un fenómeno recurrente en países que aún conservan tradiciones de sus pueblos originarios, en un intento por reinventar ese imaginario ancestral. El corpus que se comentará a continuación menciona o estudia aquellas obras costarricenses que en los siglos XX y XXI han tomado elementos de las culturas primigenias como temática central para su elaboración. Ello permitirá dar respuesta a la segunda y tercera pregunta de investigación, las cuales se enfocan en desentrañar los elementos o prácticas aborígenes que han sido apropiadas por estos compositores y las combinaciones instrumentales de las que se valen para realizar esa reinvención sonora.

Dos artículos de Gerardo Meza dan cuenta de la influencia de las culturas primigenias en la creación musical centroamericana. El primero de ellos, "La música escénica en Centroamérica" (2009) se refiere a la interacción entre música y literatura, en este tipo de obras, enmarcadas dentro de la tendencia nacionalista que afloró en la segunda mitad del siglo XX. Sin embargo, el autor asegura que "el lenguaje musical no siempre reelaborará 
elementos del entorno, más bien es la temática literaria y no la musical la que identificará el nacionalismo" (p. 145). Asimismo, menciona la trilogía de cantatas escénicas concebida por Acevedo con temas de los pueblos aborígenes costarricenses: Mamaduka (1983), Serrabá (1986) y Sukia (1997) (p. 146).

En su segundo artículo, "Mario Alfagüell: su música y un paradigma", Meza (2010) establece analogías entre el modelo de la postmodernidad y la obra creativa de Mario Alfagüell. El autor asegura que el compositor "tiene algo de miniaturista, aunque este miniaturismo pueda ser reminiscencia del pequeño arte precolombino costarricense" (p. 8), refiriéndose, específicamente, a los pequeños elementos que conforman su discurso e, incluso, la nomenclatura utilizada por el compositor. Meza (2010) culmina esta idea al afirmar que, dicho elemento "forma parte del museo imaginario" que contiene cada ser humano/creador (p. 9). Sin embargo, no aporta ejemplos concretos de obras que hayan sido concebidas por Alfagüell con influencia de la cultura precolombina.

En 2012 fue publicado el libro Música académica costarricense: del presente al pasado cercano, de las autoras Ekaterina Chatski, María Clara Vargas y Tania Vicente. El apartado suscrito por Vargas toma como tronco principal su publicación del año 2004, comentada aquí con anterioridad. Entre los aspectos enriquecidos para la actual propuesta, la autora hace referencia a Marvin Camacho, quien "externa su acercamiento a los sonidos y melodías indígenas" (p. 47), sin embargo, no menciona una obra en particular. Por su parte, Chatski dedica un capítulo del libro al análisis estilístico de una selección de obras de catorce compositores costarricenses nacidos a lo largo del siglo XX. Su estudio se apoya en los testimonios ofrecidos por los propios creadores o sus colaboradores cercanos, aspecto que complementa el trabajo de observación de la partitura. Mientras que, Vicente expone las biografías de catorce compositores nacionales -actualizadas hasta junio de 2009-, a lo que añade una lista de obras, las ediciones en partitura realizadas hasta la fecha, las grabaciones discográficas de algunas de las obras y las publicaciones que versan sobre estos creadores, de manera que el lector pueda ampliar su acercamiento a los mismos. Tanto Chatski como Vicente hacen mención a obras que son de interés para el objeto de estudio, las cuales se comentarán en el siguiente apartado.

Ese mismo año, Camacho (2012a) publicó el artículo "El realismo mágico en el canto indígena bribri y su impacto en la música contemporánea costarricense". Este trabajo, junto a Chatski (2012a) son los primeros textos dedicados a comentar cómo alguno de los elementos descritos en las publicaciones anteriores (1986 a 2011) incide directamente en la creación y, por consiguiente, está presente en las obras de compositores académicos 
Prácticas sonoras de las poblaciones aborígenes de Costa Rica

y su influencia en la música académica costarricense de los siglos XX y XXI:

hacia una historiografía de imaginarios sonoros (1986-2016)

costarricenses, como lo es el canto aborigen. Camacho toma como punto de partida el término "real maravilloso" expuesto por Alejo Carpentier en el prólogo de su novela El Reino de este mundo (1949), a partir del cual asegura:

Si bien el realismo mágico está supeditado a una característica de la literatura, he considerado pertinente que, al hablar, estudiar e interiorizar la música indígena bribri se reutilice tal concepto como un recurso que nos permita comprender mejor el fuerte ligamen existente entre el diario quehacer musical indígena y el elemento mágico sobre el cual se construye y genera toda su cultura (Camacho, 2012a, p. 87).

Al igual que en las publicaciones de Acevedo (1986) y Cervantes (1991, 1992 y 1995), Camacho dedica parte de su texto a describir algunos de los cantos y el contexto en los que son ejecutados. Sin embargo, para dar respuesta a la utilización del concepto carpenteriano, el autor hace alusión al Awá: curandero y chamán, cuya melodía puede extenderse hasta ocho noches, en dependencia de la gravedad del enfermo. De acuerdo con Camacho, "es aquí donde se aprecia con mayor claridad la fusión entre el mundo real y el mundo mágico, en el que se confiere a esta música un realismo mágico único en el desarrollo musical de nuestros pueblos indígenas" (2012a, p. 88).

El objetivo principal de su artículo se ve reflejado en el apartado final, dedicado al listado de algunas de las obras que cinco compositores costarricenses (Acevedo, Alfagüell, Alejandro Cardona, Eddie Mora y el propio Camacho) han escrito con elementos de las culturas aborígenes del país, fundamentalmente, mediante la utilización de cantos autóctonos. El autor resalta el empleo de los formatos musicales en dichas partituras -aunque de manera no exhaustiva- al hacer referencia al uso de melodías aborígenes en algunas de ellas y cómo son abordadas por sus creadores. Camacho concluye que, en las últimas tres décadas, la composición musical contemporánea, en Costa Rica, ha mirado más hacia sus raíces aborígenes, "hacia un pueblo que, pese a la adversidad de una conquista y dominación desmedida e injusta, ha sabido preservar su cultura desde lo más ancestral de la misma: la comunidad bribri" (2012a, p. 92).

Durante el siglo XX, el registro fonográfico devino en un material de vital importancia para la creación sonora. Aunque, en la actualidad, los caminos tomados por la tecnología de avanzada -unido al posicionamiento de internet- han dejado al disco compacto casi en desuso, acudir a este, es recurrente para que los creadores e intérpretes plasmen sus trabajos, en un intento por compartir y perpetuar su legado artístico. En Costa Rica, la producción discográfica ha ido creciendo en las últimas décadas, a partir del interés personal de los compositores nacidos desde la década de 1950, quienes se han ocupado de registrar parte de sus catálogos con tal fin. En el caso específico del tema que ocupa esta investigación, deben mencionarse varias producciones dedicadas parcial o íntegramente a registrar obras 
con influencias de las culturas primigenias. Para ello, hemos acudido a las notas discográficas o musicológicas que acompañan a estos álbumes y a los textos producidos posteriormente, cuyo contenido se refiere a nuestro tema. Este acercamiento nos permite vislumbrar un nuevo camino en la investigación académica, por cuanto estos materiales constituyen fuentes valiosas de conocimiento.

En 2012, Mora lanzó su disco Mujeres, dedicado íntegramente a obras suyas con inspiraciones en figuras femeninas, entre ellas Sula', "diosa de la mitología bribri"; la escritora mexicana Sor Juan Inés de la Cruz; y las escritoras costarricenses Carmen Lyra y Yolanda Oreamuno. En las notas al disco publicadas por Chatski (2012b) en la página web del compositor, vemos que las obras contienen alegorías a otros personajes femeninos de la cultura bribri, sin ser clarificados: "[en] ¿Quién amanece?, el canto pertenece a un personaje femenino que narra su historia de amor, confiándonos su secreto con optimismo y fe en si misma [sic]" (párr. 3); y "en Ye' Sulé, la cita musical aparece en una atmósfera sonora floreciente que representa los pensamientos de una mujer dirigidos hacia los misterios de la Originadora, la creadora del inmenso mundo" [itálicas añadidas] (párr. 4). En 2012, Camacho publicó su primer disco monográfico: Rituales y Leyendas, para el cual escribió las notas que inician así:

“¿Y qué es un ritual?", preguntó el Principito, que no acostumbraba a quedarse con una pregunta. A esta interrogante el Zorro contestó: "algo que olvidaron hace tiempo los humanos." En ese intento de recuperar la memoria perdida, es que titulo a este disco compacto Rituales y Leyendas. En él comparto mis propios rituales y las leyendas de vida que me han conducido como compositor (Camacho, 2012b, párr. 1).

De esta forma podemos comprender que Camacho se interesa, especialmente, por desarrollar un imaginario sonoro a partir del concepto del "ritual como paradigma estético" planteado por Susan Campos (2013) en su ensayo acerca de los primeros fonogramas de Camacho, Rituales y Leyendas y Salmos Cotidianos (2013). En este trabajo, titulado "El ritual como paradigma estético. Dos monográficos dedicados al compositor Marvin Camacho", la autora comenta sus postulados sobre la creación que se ejerce desde la región latinoamericana y cómo Camacho ha sabido construir un lenguaje propio, alejándose de las prácticas que dominan el mercado actual. Dentro de su discusión, rescatamos algunas ideas relacionadas con el objeto de estudio, en su propósito por dar respuesta a la pregunta que origina su trabajo: 
Prácticas sonoras de las poblaciones aborígenes de Costa Rica

y su influencia en la música académica costarricense de los siglos XX y XXI:

hacia una historiografía de imaginarios sonoros (1986-2016)

La música de Marvin Camacho conforma un pensamiento sonoro que evidencia "el ritual" y "el ceremonial" como entes constructores dentro de la música "de arte" actual, desde su apropiación de un patrimonio indígena -el Bribri, por ejemploy en consonancia con preocupaciones identitarias muy presentes en la creación e investigación costarricense desde principios del siglo XX (Campos, 2013, p. 126).

De acuerdo con Campos (2013), se trata de un acercamiento que "evidencia un complejo entramado simbólico y poiético", mientras hace alusión a "la corpografía de la creación, el imaginario encarnado que construye el compositor", al aseverar que ambos álbumes ofrecen "la posibilidad de pensar la discontinuidad de la experiencia humana, en este caso, conservada y construida a través de la materia musical y sonora" (pp. 126-127). Lo que plantea la musicóloga respecto al "ritual como paradigma estético" ha sido una constante en varios compositores costarricenses, quienes han encontrado en las prácticas sagradas aborígenes el misticismo como elemento primordial para la búsqueda del espectralismo sonoro que se aprecia en sus obras.

En 2014, Ivette Rojas publicó su artículo "La composición de óperas en Costa Rica a partir de 1950", en el cual repasa la labor creativa de los compositores nacionales, específicamente, para este género de las artes escénicas. El texto tiene un carácter eminentemente descriptivo, en el que la autora menciona al compositor, libretista, elenco que realizó el estreno, procedencia del presupuesto económico que permitió la primera puesta en escena, entre otros aspectos generales. Como parte de las características de las partituras, cita aquellas que contienen elementos de las culturas primigenias: Mamaduka (1983), El Sukia (1986) y Juan Serraba (1997): trilogía de cantatas escénicas compuestas por Acevedo (que fueron mencionadas anteriormente por Meza y Camacho); La Fábula en el bosque, de Alfagüell, estrenada en 2006 (no especifica el año de composición), y El Delfín de Corubicí (1993), de Andrés Saborío Bejarano.

También, en 2014, Campos publicó su ensayo "¿Arqueologías sonoras del presente?", cual manifiesto filosófico que hurga en los motivos que llevan a compositores contemporáneos a acercarse a sus culturas ancestrales, la autora menciona que:

la base del problema de estudio es la identificación de un "giro etnográfico" en la creación sonora contemporánea, teniendo como guía la utilización -y expóleo- del pueblo Bribri. El problema es amplio y complejo, por esta razón la investigación tiene como primer eje de análisis la construcción de "lo indígena" en la creación actual y su vinculación histórica con la "invención"; consciente de que, desde la investigación académica, se forma parte de esta acción -problema-y se transita por ese "camino" (Campos, 2014, p. 31). 
Campos utiliza la obra Siete Haikus (2010) ${ }^{3}$ de Camacho como materia prima para deconstruir y pensar los conceptos de la "decolonización como camino de invención" o "La Historia como Escucha", partiendo del hecho de que el compositor emplea expresiones artísticas de diversa índole a manera de condensación cultural en sí mismo: el haiku (tipo de poesía japonesa), un sorbón bribri y unos versos de su propia autoría. Además, la autora advierte sobre la necesidad de estudiar la performatividad de Camacho como intérprete de su partitura y la vinculación con el video arte de José Pablo Porras ${ }^{4}$ (pp. 32-37). A modo de conclusión, asegura que el "'gesto decolonial' [de Camacho], si cabe aquí utilizar el término a nivel hermenéutico, radica en la construcción de una especie de cosmogonía personal donde los elementos etnográficos son llevados a esenciales mítico-simbólicos" (p. 37).

Ese mismo año, Mora publicó su disco Bosque adentro, cuya temática versa -mayoritariamente- en torno a las culturas precolombinas costarricenses, fonograma que es acompañado por textos de Chatski y Henning Jensen. La primera hace referencia a los elementos que originaron las obras como, por ejemplo, un petrograbado ubicado en el Monumento Nacional Guayabo y un canto femenino bribri, y ofrece información respecto a los dedicatarios de las partituras. Mientras que Jensen se refiere a la música contenida en este álbum como "un ejemplo de estas hibridaciones y fertilizaciones cruzadas, de encuentro de culturas y tradiciones, en un contexto de creativa renovación” (2014, párr. 5).

Por su parte, el disco-libro Las memorias de Sibö (2015), cuya autoría pertenece a Camacho, recoge nueve memorias escritas por el compositor, a partir de la experiencia vivida luego de varias estancias en las comunidades aborígenes costarricenses junto a Acevedo. Casi treinta años tuvieron que transcurrir para que se publicaran, no solo estas historias que recrean el imaginario cultural de los pueblos bribri y cabécar, sino para que Camacho concibiera una partitura a cinco de estas memorias, de manera que, los sonidos convivieran en total armonía con el texto literario base. En las notas discográficas de este álbum, "Aerofónicas demiúrgicas: Pensar desde el 'sonido propio' memorias de 'lo indígena'”, Campos (2015) reitera su posición sobre el "imaginario encarnado que construye cada compositor", el cual "requiere de herramientas hermenéuticas capaces de acercarse no solo a la producción notada y grabada, sino al pensamiento simbólico y poiético" (párr. 3). En su valoración sobre dicho fonograma, la autora hace referencia a este como un "re-memorar" desde los restos de una cultura -en tanto reconstrucción del pasado- tenida, en este caso, como

3 Campos cita la obra como Los Siete Haikus. Sin embargo, Camacho (2012a) lo hace como Siete Haikus, de ahí que en el presente artículo ponderemos el nombre que le dio el compositor a su obra.

4 Puede consultarse el video en https://www.youtube.com/watch?v=jmzABh||G3| 
Prácticas sonoras de las poblaciones aborígenes de Costa Rica

y su influencia en la música académica costarricense de los siglos XX y XXI:

hacia una historiografía de imaginarios sonoros (1986-2016)

una especie de "arqueología del presente" (párr. 7). Así, trasciende la práctica común que, durante el siglo XX, acudió a las culturas aborígenes como "materia prima" para demarcar las tendencias nacionalistas.

Para Campos, devolverse hacia lo ancestral del individuo no es algo novedoso, como tampoco lo es recurrir al cliché de "lo indígena". La autora asegura que la obra de Camacho remite a "la Creación, a la pérdida y al desencanto ... a La Familia desmembrada ... a la fertilidad de las cenizas" (2015, párr. 10). De igual forma, concluye afirmando que Las memorias de Sibö son, ante todo, un acto de imaginación, cual reinvención de un imaginario cultural, llevado aquí a la palabra y la música como resultado de una profunda meditación y conciencia del pensamiento propio.

Una de las publicaciones recientes que también aborda la presencia del canto bribri en una obra en concreto es el ensayo "Concierto para viola, sobre un canto bribri. Hacia una interpretación" de Orquídea Guandique (2016), incluido en el libro Benjamín Gutiérrez. La música es mi destino. El Concierto para viola (1982-1983) de Gutiérrez es la obra objeto de estudio, a partir de la cual la autora realiza un análisis estructural. Guandique resalta un aspecto fundamental de la partitura que es, precisamente, el subtítulo "Sobre un canto bribri", que hace alusión directa a la influencia de esta cultura a la hora de ser concebida. A pesar de ello, contrasta varias fuentes que apoyan y desmienten la presencia directa de un canto bribri en la construcción melódica de la obra. En un principio, Gutiérrez aseguró al periódico La Nación haberse sentido atraído por uno de los cantos incluidos por Acevedo en su publicación etnográfica Ye Stsöke, Yo Suelo Cantar (1980). Sin embargo, veintisiete años después desmintió esta afirmación, aludiendo que la obra no se refiere directamente a un canto bribri, sino que el subtítulo responde al creciente interés de la época (década de 1980) por traer, a la creación académica, la herencia cultural y musical de los pueblos originarios de Costa Rica. De cualquier forma, Guandique afirma que:

No hay una definición clara del material temático extraído de las canciones bribri de la compilación de Acevedo. Sin embargo, independientemente de que el compositor citase o no elementos de la música bribri, está claro que la obra posee un significado explícito a la práctica musical de un grupo cultural y, a su vez, le rinde homenaje, no por el uso de citas, sino por la referencia explícita en el título (Guandique, 2016, p. 107).

Después de comentadas estas publicaciones, vemos cómo a partir de 2009 comienza una nueva tendencia, en la que se hacen referencias a obras producidas en Costa Rica con títulos o inspiraciones aborígenes. Sin embargo, no todos los autores profundizan en esos elementos que dan lugar a las obras en cuestión. Hasta las publicaciones de Chatski, Camacho, Campos y Guandique es que encontramos, por primera vez, una alusión directa o discusión 
del cómo están presentes algunos elementos de los pueblos originarios en la obra de compositores académicos costarricenses, en este caso, a través del ritual y los cantos bribris y cabécares. Estos textos comienzan a marcar una nueva tendencia, donde se estudia la influencia que han ejercido las prácticas sonoras de las culturas aborígenes, de forma directa, en la música producida en Costa Rica, durante la última mitad del siglo XX y lo que va del XXI. Estos se enfocan en descifrar dichos elementos y reflexionar sobre los motivos que llevaron a los compositores a utilizarlos, aspecto que merece un acercamiento mucho más enriquecedor.

En las publicaciones consultadas, algunas partituras han sido objeto de análisis, otras solamente mencionadas, incluso, con escasos datos que impiden una referencia adecuada. A modo de anexo, ofrecemos una tabla que contiene la lista de estas partituras, respetando la información que ofrecen las publicaciones, de manera que el lector pueda constatar la afirmación anterior. En esta relación de obras no se incluyen las transcripciones de melodías y cantos aborígenes mencionados y/o anexados en los textos, ya que estos no constituyen una creación propia en sí, que desde el presente recree el imaginario sonoro de los pueblos nativos. Este tipo de documentos no son reconocidos en la presente investigación como obras artísticas, sino como transcripciones notadas de las melodías y cantos originales de dichas culturas.

Como se podrá apreciar en la tabla, los datos de las obras no fueron aportados de igual forma por los investigadores, lo cual requerirá estudios futuros que contribuyan a una mejor argumentación, en aras de establecer un panorama completo del repertorio concebido en Costa Rica con estas características. Ello permitirá profundizar acercamientos comparativos que evidencien los formatos preferidos y los recursos de los que se valen sus autores para recrear el imaginario sonoro de dichos pueblos. No obstante, con el propósito de dar respuesta a la segunda y tercera interrogantes que motivaron esta investigación, comentaremos los datos colectados.

En primer lugar, Meza (2009) solo menciona las tres cantatas escénicas de Acevedo y en su artículo (2010) no hace referencia a obras específicas de Alfagüell con influencia de las culturas aborígenes. Seguidamente, Rojas (2014) hace mención a las obras escénicas con inspiración en los pueblos originarios, concebidas por Acevedo, Alfagüell y Saborío. Empero, tampoco aporta insumos respecto a las características musicales o elementos que sirven de soporte para su creación. En tercer lugar, en Chatski (2012a) podemos encontrar referencias a obras que evocan a las culturas aborígenes: Suite de Palenque, partitura incidental de Rocío Sanz (p. 79); Concierto para viola y orquesta "Sobre un canto Bribri" de Gutiérrez, donde el compositor "no cita ningún canto bribri, sino que

5 Sobre esta obra se ahondará más adelante.

ESCENA. Revista de las artes, 2019, Vol. 79, Núm. 1 (julio-diciembre), pp. 177-207 
Prácticas sonoras de las poblaciones aborígenes de Costa Rica

y su influencia en la música académica costarricense de los siglos XX y XXI:

hacia una historiografía de imaginarios sonoros (1986-2016)

hace una alusión a los cantos de pueblos nativos americanos; es decir, ...concibe dichos cantos a su modo, empleando la escala modal e intervalos paralelos de cuartas y quintas" (p. 105); Otra sinfonía de despedida op. 102, sobre los textos indígenas de Fernando Güell (p. 131) y la canción Temporal cerrao (pp. 143-144), ambas de Mario Alfagüell. Respecto a los recursos utilizados por este compositor para crear algunas de sus canciones, Carmen Méndez, en comunicación personal con Chatski, asegura que:

son utilizadas por el compositor como materia prima, transformándolas mediante procesos matemáticos con los que llega a las proporciones, para elaborar los ritmos, las alturas, los conglomerados de sonidos, los matices, la forma, el número de veces que aparecen los acontecimientos sonoros, la instrumentación, entre otros. Esos números se usan tan sistemática como arbitraria o libremente; están determinados por el tamaño de los intervalos de la melodía original, según su número de semitonos. Pueden ser transformados hasta el infinito, como aumentarles o disminuirles a todos un 1, un 2, un 3, un 4, entre otras (citado en Chatski, 2012a, pp. 143-144).

Al referirse a la obra creativa de Cardona, tanto Chatski como las consideraciones del propio compositor citadas en el texto, hacen mención a las diversas influencias presentes en su música: "rondas infantiles, tonadas populares españolas y mexicanas, sones montunos, cantos indígenas, diversos complejos rítmicos de origen afroantillano, como tumbaos mambescos y soneros, diversas claves y ritmos de origen Yorubá y Bantú" (2012a, p. 183). Sin embargo, en ningún momento queda explícita la referencia directa a una obra en particular inspirada en las culturas originarias de Costa Rica6 .

En las obras de Camacho, Chatski resalta el hecho de que Lamento bribri exige una participación más activa de los intérpretes, en tanto deben hacer uso de varias técnicas extendidas, como la declamación por parte de los músicos y "el empleo percutido de cada voz". Además, señala que la obra no está escrita en un pentagrama tradicional, sino que el compositor se vale de indicaciones temporales (segundos) para la ejecución de los diferentes diseños o pasajes, así como "la inserción de dos niveles politiempales"” (2012a,

${ }^{6}$ Algunos de los títulos traídos a colación hacen referencia explícita a culturas ancestrales, tal es el caso de: Xikiyeua in Xochitl y Tlanéhuatl. Sin embargo, es muy probable que hayan sido inspiradas en personajes y situaciones propias de las poblaciones mexicanas, por su constante presencia en la obra creativa de Cardona.

7 De acuerdo con la autora, "con el término técnico 'politiempal' nos referimos a la unión simultánea de varias voces con diferente duración en segundos" (Chatski 2012a, p. 227).

ESCENA. Revista de las artes, 2019, Vol. 79, Núm. 1 (julio-diciembre), pp. 177-207 
p. 227). Por último, asegura que, en Meditación "se escucha el canto de la fiesta de los huesos; y en el séptimo haiku, un canto bribri. Sin embargo, en Chamánicos y Lamento bribri Camacho presenta una interpretación propia de los rituales indígenas y las culturas nativas" -sin especificar de qué forma ni en qué lugar de la partitura se encuentran estos elementos- (2012a, p. 233).

En cuarto lugar, Vicente (2012) se limita a ofrecer las listas de obras en las que no siempre especifica los años de composición u otros datos relevantes para el objeto de estudio. Sin embargo, es la publicación en la que se encontraron mayor cantidad de las obras incluidas en la tabla 1. En quinto lugar, nuevamente Chatski (2012b) asegura que las tres obras de Mora "fueron concebidas a partir de una cita musical: el canto femenino de la población nativa bribri" (párr. 3), sin especificar a cuál o cuáles de los cantos se remitió el compositor para desarrollar sus propias concepciones sonoras. Seguidamente, Camacho (2012a) se refiere a la trilogía de Acevedo "como expresión instrumental y como material compositivo [a] una serie de cantos propios del sorbón bribri, cantos varios y sus propias reinterpretaciones musicales del lenguaje indígena" (p. 90). Al tener en cuenta que, el autor narra la presencia del canto aborigen en las obras de los cinco compositores mencionados por él, vemos cómo, acudir a la voz no fue solo un recurso empleado por Avecedo, sino también por Alfagüell en su Fábula del bosque opus 173 y el propio Camacho en Lamentos Bribris, Siete Haikus, Juego \# 3 de cuentos y leyendas y segunda sinfonía Humanidades, en cuyo primer movimiento utiliza un canto grabado por Acevedo en su disco Ye Stöke (p. 92) ${ }^{9}$.

Según la relación de obras expuestas en la tabla 1, el piano ha sido el instrumento solista preferido por los compositores. Empero, Camacho (2012a) no siempre especifica cómo se encuentra la presencia del canto aborigen en las partituras. Es decir, si el intérprete debe utilizar la voz para entonar una melodía (en forma de vocalizo o mediante textos originales) o si el canto es ejecutado directamente en el teclado. Los únicos casos en los que el autor aclara estos elementos son, por ejemplo, en las partituras compuestas por Alfagüell, quien:

ha utilizado un solo tema indígena de carácter polifónico para todas sus obras, [el cual] no es literal, es más bien el empleo de la relación interválica que se obtiene de la melodía y partiendo de esta [relación] numérica se establecen diferentes cánones de desarrollo para las obras ... Alfagüell hace caso omiso del ritmo que

8 Se refiere a la obra Meditación bribri para contrabajo solo.

9 Los títulos de las obras son citados aquí tal cual lo hace el autor en su ensayo. 
Prácticas sonoras de las poblaciones aborígenes de Costa Rica

y su influencia en la música académica costarricense de los siglos XX y XXI:

hacia una historiografía de imaginarios sonoros (1986-2016)

contiene el canto bribri original y busca, sobre todo, desfasar el concepto rítmico establecido en el canto, creando además grandes momentos de improvisación que convierten al intérprete en coautor de la obra (Camacho, 2012a, pp. 90-91).

Estos detalles también los ofrece en su propia obra Siete Haikus, donde argumenta que "en el último [haiku], un sorbón bribri es cantado por el pianista, mientras se establecen una serie de enlaces armónicos no tradicionales que complementan armónicamente su canto" (p. 92). Y, aunque no se trata de una obra para piano, en Diálogo Guerreo Místico opus 15 para dos guitarras, el autor aclara que Alfagüell:

experimenta con sonoridades producidas por el uso de arcos que frotan en algunas ocasiones la cuerda prima y la sexta de la guitarra. Con esto logra texturas diferentes del instrumento que incluso nos remiten a ciertas texturas ingenuas y de carácter primitivo, presentes en algunos cantos y música indígena de Latinoamérica (Camacho, 2012a, p. 91).

Así, las interrogantes quedan para: la "serie de seis obras cortas para piano [de Acevedo] ... basadas en cantos indígenas bribris transcritos por él"; Alala de Cardona, "que toma como base una canción de cuna, género muy presente en el desarrollo del canto bribri asociado con la feminidad"; Zachic 3 y Cuarteto \# 6, donde Cardona "aborda nuevamente la temática indígena a través de nuevas texturas y atmósferas que nos conducen a la reinterpretación del lenguaje indígena por parte del compositor"; Chamánicos, "donde el título nos remite a ese concepto religioso"; Antonio, "donde utiliza claramente una canción de cuna bribri", ambas de Camacho. Además, las obras de Mora, inspiradas en la obra literaria de Adolfo Constenla, Poesía Bribri de lo Cotidiano (2006), y desde la que el compositor toma como protagonista a la mujer aborigen, según se comentó anteriormente (Camacho, 2012a, pp. 91-92).

Campos (2013) afirma que en el Concierto para piano, cuerdas y percusión de Camacho "no hay ningún lirismo, sino un canto chamánico que invoca lo innombrable" (p. 125). Por su parte, Chatski (2014) aclara que Caminos de piedra y Caminos de agua, ambas de Mora, fueron concebidas tomando como imagen simbólica un petrograbado precolombino ubicado en el Monumento Nacional Guayabo (párr. 1). En una cita al compositor, este asegura que los instrumentos solistas de dichas partituras (piano y cello, respectivamente) representan a un personaje imaginario en su camino de vida hasta la muerte, al tiempo que nos deja saber que la función de la orquesta y la percusión (masas sonoras acompañantes en cada caso) es la de envolver a dicho personaje para recrear el bosque húmedo costarricense (citado en Chatski, 2014, párr. 1). En cuanto a Ye' Sulé I y Ye' Sulé II, Chatski señala que, se basan en el mismo canto bribri, tomado del libro de Constenla (2006), sin ahondar en las características del 
mismo. Para finalizar, se refiere a lo que ella llama "dos momentos musicales", Bosque adentro I-II -que son las pistas que abren y cierran el disco homónimo- cuya sonoridad, compuesta de ocarinas y percusiones, hace alusión a "la cultura precolombina" (párr. 4) ${ }^{10}$.

Por su parte, Campos (2014) asegura que las primeras obras costarricenses concebidas a partir de la temática aborigen están registradas en archivos como partituras y grabaciones en audio y/o video a partir de 1922 (p. 31). En tanto, las más recientes tienen en Acevedo, Alfagüell, Cardona, Otto Castro, Carlos Castro, Camacho y Mora a los compositores más representativos. Sin dejar de lado a Mauricio Zamora, los artistas sonoros Alejandro Sánchez -alias Achromatic Prods-y Sergio Fuentes -alias Sergio Wiesengrund-, el Proyecto Jirondai y "el grupo de rock instrumental Niño Koi", como parte de una generación más joven que contribuye a sostener el mismo interés de los anteriormente citados (p. 32). En su ensayo, la autora reflexiona acerca de la heterogeneidad de influencias en la obra Siete Haikus de Camacho, incluido el sorbón bribri que aparece en el último de estos haikus. Menciona dos obras de Alfagüell, sin mayores datos y solo nombra a otros compositores/artistas, sin aludir a una obra en concreto.

Finalmente, Guandique (2016) hace referencia a varios compositores que se han visto influenciados por los cantos bribris, entre ellos, Acevedo, Camacho y Mora. Sin embargo, junto a ellos aporta el nombre de Carlos Castro -al igual que Campos (2014)-, sin hacer alusión a una obra específica, como en ninguno de los casos donde se menciona. Lo anterior obliga a seguir profundizando en la búsqueda de este repertorio, en aras de conformar un catálogo completo de las partituras que contienen elementos de las culturas primigenias de Costa Rica.

\section{Conclusiones}

Luego de realizar este recuento historiográfico podemos concluir que durante el período estudiado se establecen dos tendencias principales. La primera, entre 1986 y 2011 , con publicaciones que abordaron el tema de las prácticas sonoras de las culturas aborígenes desde una perspectiva descriptiva, al tratar elementos histórico-sociales, características de los instrumentos, diferentes tipos de géneros y cantos, y la transcripción de dichas melodías en un pentagrama occidental. El corpus estudiado denota un interés creciente por acercarse a estas comunidades, ayudándonos a entender que los comportamientos sociales llevan intrínseco un alto componente cultural, en tanto la práctica recurrente de sus cantos no es exclusiva de convivios festivos o religiosos, sino que marcan el diario bregar de estos pueblos.

\footnotetext{
${ }^{10}$ Por la denominación que hace la autora, no podemos distinguir si se trata de obras musicales escritas en partitura o de improvisaciones que no siguen un orden metódico previamente concebido. Es por ello que estos "dos momentos musicales" no fueron incluidos en la tabla 1.
} 
Prácticas sonoras de las poblaciones aborígenes de Costa Rica

y su influencia en la música académica costarricense de los siglos XX y XXI:

hacia una historiografía de imaginarios sonoros (1986-2016)

La segunda tendencia se extiende entre 2009 y 2016, con artículos, ensayos, capítulos de libros, notas discográficas y entradas de blogs, en las que se mencionan obras contemporáneas que toman insumos de estos comportamientos socioculturales para concebir partituras originales. Algunas publicaciones solo hacen mención a las obras, mientras que otras intentan encontrar respuesta a motivaciones filosóficas que llevaron a los compositores a interesarse por esta temática. En el caso de esta última variable, Campos inicia un camino sugerido por Cervantes (1991a y 1995), cuando hacía un llamado a abordar el fenómeno de las prácticas musicales aborígenes desde la relación música-mito-ritual. Esta merece acercamientos más exhaustivos que contribuyan a generar un canon en torno al tema, pues su reciente abordaje es insuficiente para dialogar sobre esta perspectiva de análisis.

Las publicaciones arrojaron que el elemento utilizado con mayor frecuencia por los creadores es el canto, ya que constituye una manifestación sonora per sé. La reinvención no solo está dada aquí por el hecho implícito de tomar una línea melódica, sino por el contexto sonoro en el que cada uno de ellos la desarrolla, ligado íntimamente a su lenguaje personal. Las combinaciones instrumentales empleadas son diversas, pues van desde un instrumento en solitario -como el piano o la guitarra- hasta formatos de mayor pretensión como el sinfónico-coral. Esto se debe, principalmente, a la forma en la que cada creador realiza la escucha interior o se apropia de los cantos preferidos. Ejemplo de ello es la presencia de estas líneas melódicas, de formas más o menos explícitas, ya que unos han empleado la entonación del texto mediante la voz, mientras que otros han preferido encomendárselas a instrumentos diferentes.

Así, damos respuesta a nuestras preguntas de investigación. Sin embargo, no debemos olvidar que la lista de obras elaborada a partir de estas publicaciones evidencia que no todos los autores aportaron la información completa de dichas partituras. Esto obliga a realizar un estudio futuro, si se quiere contar con un catálogo íntegro de la música producida en Costa Rica con influencia directa de sus culturas aborígenes.

\section{Referencias}

Acevedo, J. (1986). Música en las reservas indígenas de Costa Rica. San José: Editorial de la Universidad de Costa Rica.

Borge, C. \& Villalobos, V. (1994). Talamanca en la encrucijada. San José: Editorial de la Universidad Estatal a Distancia.

Camacho, M. (2012a). El realismo mágico en el canto indígena bribri y su impacto en la música contemporánea costarricense. Boletín Música, 31, 87-93. 
Camacho, M. (2012b). Notas al disco. En Rituales y Leyendas.

Campos, S. (2013). El ritual como paradigma estético. Dos monográficos dedicados al compositor Marvin Camacho. Boletín Música, 35, 124-127.

Campos, S. (2014). ¿Arqueologías sonoras del presente? Boletín Música, 37, 27-43.

Campos, S. (2015). Aerofónicas demiúrgicas: Pensar desde el "sonido propio" memorias de lo indígena. Notas al disco-libro. En Marvin Camacho (compositor), Las memorias de Sibö.

Carballo, J. (2008). Los grupos indígenas costarricenses. Recuperado de https://docplayer. es/13365864-Los-grupos-indigenas-costarricenses.html

Cervantes, L. (1990). Súlar: Playing for the Dead. A Study of Bribri Funerary Chants as Speech Acts. (Tesis de Maestría en Antropología). Universidad Estatal de Nueva York, Albany, Estado Unidos.

Cervantes, L. (1991a). Los géneros musicales bribris: aspectos sociolingüísticos de su ejecución. Revista Káñina, 15(1-2), 243-254.

Cervantes, L. (1991b). Observaciones etnomusicológicas acerca de tres cantos de cuna cabécares. Estudios de Lingüística Chibcha, 10, 143-163.

Cervantes, L. (1991c). La temática de los cantos fúnebres bribris. Estudios de Lingüística Chibcha, 17(1-2), 81-104.

Cervantes, L. (1992). La función social de la música en el ritual fúnebre bribri. Revista Káñina, 16(1), 245-265.

Cervantes, L. (1993). Origen y destino de las almas después de la muerte en la religión bribri. Revista Káñina, 17(2), 213-223.

Cervantes, L. (1995). Información básica acerca de la música tradicional indígena de Costa Rica. Revista Káñina, 19(1), 155-173.

Cervantes, L. (2003). Sounds like music: ritual speech events among the Bribri Indians of Costa Rica (Tesis doctoral). Universidad de Texas, Austin, Estados Unidos.

Chatski, E.; León, T. \& Vargas, M. (2012a). Música académica costarricense. Del presente al pasado cercano. San José: Editorial de la Universidad de Costa Rica.

Chatski, E. (2012b). Notas al disco. En Eddie Mora (compositor), Mujeres. Recuperado de: http://eddiemora.com/es/2016/07/09/mujeres/

Chatski, E. (2014). Notas al disco. En Eddie Mora (compositor), Bosque adentro. 
Prácticas sonoras de las poblaciones aborígenes de Costa Rica

y su influencia en la música académica costarricense de los siglos XX y XXI:

hacia una historiografía de imaginarios sonoros (1986-2016)

Fonseca, O. (1996). Historia antigua de Costa Rica: surgimiento y caracterización de la primera civilización costarricense. San José: Editorial de la Universidad de Costa Rica.

Guandique, O. (2016). Concierto para viola, sobre un canto bribri. Hacia una interpretación. En Ekaterina Chatski (Ed.), Benjamín Gutiérrez. La música es mi destino (pp. 87-112). San José: Radioemisoras de la Universidad de Costa Rica.

Jensen, H. (2014). Notas al disco. En Eddie Mora (compositor), Bosque adentro.

Margery, E. (1991). Notas en torno a la forma y contenidos de una muestra de cantos de cuna cabécares. Estudios de Lingüística Chibcha, 10, 121-141.

Meza, G. (2009). La música escénica en Centro América. Revista Estudios, 22, 143-154.

Meza, G. (2010). Mario Alfagüell: Su música y un paradigma. Revista Estudios, 23, 1-12.

Mignolo, W. (2007). La idea de América Latina. Barcelona: Editorial Gedisa.

Montero, D. (2013). Identidad cultural como manifestación estética: propiedad o ajenidad en Latinoamérica. Revista ESCENA, 72-73(1-2), 33-38.

Montero, D. (2016). El estudio estético y del binomio identidad-alternada (nosotros-otros) occidental. ESCENA. Revista de las artes, 75(2), 115-126.

Paz, C. (2010). Algunas miradas sobre la música indígena costarricense. Revista Herencia, 23(2), 49-54.

Paz, C. (2011). Paisajes sonoros e identidad en la juventud indígena bribri. Revista Estudios, 24, 1-32.

Pérez, J. (2007). La historiografía musical hispanoamericana. Estado actual. Boletín Música, 18, 3-17.

Peytrequín, J. (2011). Identidad y prácticas rituales funerarias en Costa Rica, 300-800 d.C. Una interpretación. Cuadernos inter.c.a.mbio sobre Centroamérica y el Caribe, 9, 249-270.

Rojas, C. (1988). Descripción y análisis de la Fiesta de los Diablitos de Boruca. Estudios de Lingüística Chibcha, 7, 121-135.

Rojas, I. (2014). La composición de óperas en Costa Rica a partir de 1950. Revista Estudios, 28, 1-19.

Rojas, D. (2002). El conflicto entre tradición y modernidad: constitución de la identidad cultural indígena Bribri. Cuaderno de Ciencias Sociales, 126, 1-60.

ESCENA. Revista de las artes, 2019, Vol. 79, Núm. 1 (julio-diciembre), pp. 177-207 
Salazar, R. (1992). Instrumentos musicales del folclor costarricense. Cartago: Editorial Tecnológica de Costa Rica.

Salazar, R. (2002). El indígena costarricense: una visión etnográfica. Cartago: Editorial Tecnológica de Costa Rica.

Vargas, M. C. (2004). La música. En Eugenio Rodríguez (Ed.), Costa Rica en el siglo XX: (tomo I). San José: EUNED. 
Anexo:

Tabla 1. Obras costarricenses con influencia de las culturas aborígenes, citadas en las publicaciones (2009-2016)

\begin{tabular}{|c|c|c|c|c|c|c|}
\hline Compositor/a & Año de nacimiento & Obra & Formato & Año de composición & Reconocimiento & Fuente \\
\hline Rocío Sanz & 1933 & Suite de Palenque & Música incidental & 1971 & $s / d$ & Chatski, 2012a \\
\hline Bernal Flores & 1937 & Variaciones precolombinas & $\begin{array}{l}\text { Dos marimbas, flauta dulce, dos pares de cla- } \\
\text { ves, cinco tambores o timbales, bombo y güiro }\end{array}$ & $s / d$ & $s / d$ & Vicente, 2012 \\
\hline \multirow[b]{2}{*}{ Benjamín Gutiérrez } & \multirow[b]{2}{*}{1937} & Concierto para viola y orquesta & Viola y orquesta & 1985 & $s / d$ & Chatski, 2012a \\
\hline & & Concierto para viola & Viola y orquesta sinfónica & $1982-83$ & Premio Áncora 1984 & $\begin{array}{l}\text { Guandique, } \\
2016\end{array}$ \\
\hline \multirow{11}{*}{ Jorge Luis Acevedo } & \multirow{11}{*}{1948} & Seis obras para piano & Piano & $s / d$ & $s / d$ & Camacho, 2012a \\
\hline & & Canción & Dos voces solistas y piano & $\mathrm{s} / \mathrm{d}$ & $\mathrm{s} / \mathrm{d}$ & Camacho, 2012a \\
\hline & & Mamaduka & $s / d$ & 1983 & $\mathrm{~s} / \mathrm{d}$ & Meza, 2009 \\
\hline & & Cantata Escénica Mamaduka & Orquesta sinfónica, coro y solistas. & $s / d$ & $\begin{array}{l}\text { Premio Nacional Aquileo J. } \\
\text { Echeverría }\end{array}$ & Camacho, 2012a \\
\hline & & Mamaduka & Canto lírico, danza, coro y orquesta & 1983 & $s / d$ & Rojas, 2014 \\
\hline & & Sukia & $s / d$ & 1997 & $\mathrm{~s} / \mathrm{d}$ & Meza, 2009 \\
\hline & & Cantata Escénica El Sukia & Orquesta sinfónica, coro y solistas & $s / d$ & $\begin{array}{l}\text { Premio Nacional Aquileo J. } \\
\text { Echeverría }\end{array}$ & Camacho, 2012a \\
\hline & & El Sukia & Canto lírico, danza, coro y orquesta & 1986 & $s / d$ & Rojas, 2014 \\
\hline & & Serrabá & $s / d$ & 1986 & $s / d$ & Meza, 2009 \\
\hline & & Canta Escénica Serrabá & Orquesta sinfónica, coro y solistas & $s / d$ & $\begin{array}{l}\text { Premio Nacional Aquileo J. } \\
\text { Echeverría }\end{array}$ & Camacho, 2012a \\
\hline & & Juan Serraba & Canto lírico, danza, coro y orquesta & 1997 & $\mathrm{~s} / \mathrm{d}$ & Rojas, 2014 \\
\hline
\end{tabular}




\begin{tabular}{|c|c|c|c|c|c|c|}
\hline Compositor/a & Año de nacimiento & Obra & Formato & Año de composición & Reconocimiento & Fuente \\
\hline \multirow{20}{*}{ Mario Alfagüell } & \multirow{20}{*}{1948} & Fábula del bosque opus 173 & Orquesta sinfónica, coro y solistas & $s / d$ & $\mathrm{~s} / \mathrm{d}$ & Camacho, 2012a \\
\hline & & La Fábula en el bosque & $\mathrm{s} / \mathrm{d}$ & 2006 & $\mathrm{~s} / \mathrm{d}$ & Rojas, 2014 \\
\hline & & Sonatina \# 1 opus 238 & Piano & $s / d$ & $s / d$ & Camacho, 2012a \\
\hline & & Diálogo guerrero místico, Op. 15 & $\mathrm{~s} / \mathrm{d}$ & 1981 & $\mathrm{~s} / \mathrm{d}$ & Vicente, 2012 \\
\hline & & Diálogo Guerrero Místico opus 15 & Dos guitarras & $\mathrm{s} / \mathrm{d}$ & $\mathrm{s} / \mathrm{d}$ & Camacho, 2012a \\
\hline & & Diálogo guerrero místico Op. 15 & $s / d$ & 1981 & $\mathrm{~s} / \mathrm{d}$ & Campos, 2014 \\
\hline & & $\begin{array}{l}\text { Concierto para arpa y pequeña orquesta, Op. 204. Sobre } \\
\text { un canto indígena bribri de Costa Rica }\end{array}$ & $\begin{array}{l}\text { Arpa solista, clarinete piccolo en do, clarinete en } \\
\text { do, clarinete bajo, timbales, violines I-II, violas y } \\
\text { violonchelos }\end{array}$ & 2008 & $\mathrm{~s} / \mathrm{d}$ & Vicente, 2012 \\
\hline & & $\begin{array}{l}\text { Concierto para fagot y pequeña orquesta, Op. } 205 \text {. Sobre } \\
\text { un canto indígena bribri de Costa Rica }\end{array}$ & $\begin{array}{l}\text { Fagot solista, arpas, violines I-II, violas y vio- } \\
\text { lonchelos }\end{array}$ & 2008 & $s / d$ & Vicente, 2012 \\
\hline & & $\begin{array}{l}\text { Quinteto para bronces, Op. 191. Sobre un canto indígena } \\
\text { bribri de Costa Rica }\end{array}$ & Quinteto de bronces & 2007 & $\mathrm{~s} / \mathrm{d}$ & Vicente, 2012 \\
\hline & & $\begin{array}{l}\text { Concierto para piano y orquesta N }{ }^{\circ} 7 \text { Op. } 207 \text { "sobre un } \\
\text { canto indígena BRIBRI de Costa Rica" }\end{array}$ & Piano y orquesta & 2009 & $\mathrm{~s} / \mathrm{d}$ & Campos, 2014 \\
\hline & & $\begin{array}{l}\text { Otra sinfonía de despedida, Op. 102. Sobre textos indíge- } \\
\text { nas costarricenses y de Fernando Centeno Güell }\end{array}$ & $\begin{array}{l}\text { Soprano/mezzo-soprano, narrador y pequeña } \\
\text { orquesta }\end{array}$ & 1998 & $\mathrm{~s} / \mathrm{d}$ & Vicente, 2012 \\
\hline & & $\begin{array}{l}\text { Otra sinfonía de despedida op. 102, sobre los textos indí- } \\
\text { genas de Fernando Güell }\end{array}$ & $\mathrm{s} / \mathrm{d}$ & $s / d$ & $\mathrm{~s} / \mathrm{d}$ & Chatski, 2012a \\
\hline & & Canción Temporal cerrao & $\mathrm{s} / \mathrm{d}$ & $s / d$ & $s / d$ & Chatski, 2012a \\
\hline & & $\begin{array}{l}\text { Siete canciones amerindias sobre textos indígenas costa- } \\
\text { rricenses, Op. } 165 \text { a }\end{array}$ & Soprano y piano & 2005 & $s / d$ & Vicente, 2012 \\
\hline & & $\begin{array}{l}\text { Siete canciones amerindias sobre textos indígenas costa- } \\
\text { rricenses, Op. } 166\end{array}$ & Soprano y orquesta & 2005 & $\mathrm{~s} / \mathrm{d}$ & Vicente, 2012 \\
\hline & & 44 cánones, Op. 44 (Textos indígenas costarricenses) & Coro mixto & 1991 & $\mathrm{~s} / \mathrm{d}$ & Vicente, 2012 \\
\hline & & $\begin{array}{l}\text { Cantata navideña latinomaericana sobre textos indígenas } \\
\text { costarricenses, Op. } 6\end{array}$ & Coro mixto & 1976 & $\mathrm{~s} / \mathrm{d}$ & Vicente, 2012 \\
\hline & & $\begin{array}{l}\text { Cantata sacrílega sobre textos indígenas } \\
\text { costarricenses, Op. } 12\end{array}$ & Coro mixto y ensemble & 1979 & $\mathrm{~s} / \mathrm{d}$ & Vicente, 2012 \\
\hline & & $\begin{array}{l}\text { Motetes místicos y obscenos, Op. } 11 \text { (Textos del Dies Irae } \\
\text { e indígenas costarricenses) }\end{array}$ & Coro mixto & 1979-1980 & $s / d$ & Vicente, 2012 \\
\hline & & $\begin{array}{l}\text { Once oraciones, Op. } 62 \text { (Textos de Beata María Romero y } \\
\text { de fuentes indígenas costarricenses) }\end{array}$ & Coro & 1993 & $\mathrm{~s} / \mathrm{d}$ & Vicente, 2012 \\
\hline
\end{tabular}




\begin{tabular}{|c|c|c|c|c|c|c|}
\hline Compositor/a & Año de nacimiento & Obra & Formato & Año de composición & Reconocimiento & Fuente \\
\hline Andrés Saborío & 1958 & El Delfín de Corubicí (mini ópera) & $\mathrm{s} / \mathrm{d}$ & 1993 & $s / d$ & Rojas, 2014 \\
\hline \multirow{4}{*}{ Alejandro Cardona } & 1959 & Alala & Guitarra & 1982 & $\mathrm{~s} / \mathrm{d}$ & Camacho, 2012a \\
\hline & & Zachic 3 & Orquesta sinfónica & 2003 & $\mathrm{~s} / \mathrm{d}$ & Vicente, 2012 \\
\hline & & Zachic 3 & Orquesta sinfónica & $s / d$ & $s / d$ & Camacho, 2012a \\
\hline & & Cuarteto \# 6 & Cuarteto de cuerdas & $s / d$ & $s / d$ & Camacho, 2012a \\
\hline \multirow{13}{*}{ Eddie Mora } & \multirow{13}{*}{1965} & Sula & Viola y piano solistas, cuerdas y percusión & 2010 & $\begin{array}{l}\text { Premio Nacional Aquileo J. } \\
\text { Echeverría }\end{array}$ & Camacho, 2012a \\
\hline & & Sula' & $s / d$ & $s / d$ & $s / d$ & Chatski, 2012b \\
\hline & & Sula' & $\begin{array}{l}\text { Viola y piano obligados, orquesta de cuerdas y } \\
\text { percusión }\end{array}$ & 2010 & $s / d$ & Chatski, 2014 \\
\hline & & ¿Quién amanece? & Flautín, ocarina y cuerdas & 2011 & $s / d$ & Camacho, 2012a \\
\hline & & ¿Quién amanece? & $s / d$ & $s / d$ & $\mathrm{~s} / \mathrm{d}$ & Chatski, 2012b \\
\hline & & ¿Quién amanece? & Flautín, ocarina y orquesta de cuerdas & 2011 & $s / d$ & Chatski, 2014 \\
\hline & & Ye Sule 1 & Piano & 2011 & $s / d$ & Camacho, 2012a \\
\hline & & Yé Sulél & Piano & 2011 & $\mathrm{~s} / \mathrm{d}$ & Chatski, 2014 \\
\hline & & Ye Sule 2 (Camacho, 2012a) & Ensamble de vientos, piano, arpa y percusión & 2011 & $s / d$ & Camacho, 2012a \\
\hline & & Ye'Sulé & $\mathrm{s} / \mathrm{d}$ & $s / d$ & $\mathrm{~s} / \mathrm{d}$ & Chatski, 2012b \\
\hline & & Ye’ Sulé II & Ensamble de vientos, piano, arpa y percusión. & 2011 & $s / d$ & Chatski, 2014 \\
\hline & & Caminos de piedra & Piano, orquesta de cuerdas y percusión & 2012 & $s / d$ & Chatski, 2012b \\
\hline & & Caminos de agua & Violonchelo y percusión mixta & 2013 & $s / d$ & Chatski, 2012b \\
\hline
\end{tabular}




\begin{tabular}{|c|c|c|c|c|c|c|}
\hline Compositor/a & Año de nacimiento & Obra & Formato & Año de composición & Reconocimiento & Fuente \\
\hline \multirow{17}{*}{ Marvin Camacho } & \multirow{17}{*}{1966} & Meditación & $\mathrm{s} / \mathrm{d}$ & $\mathrm{s} / \mathrm{d}$ & $\mathrm{s} / \mathrm{d}$ & Chatski, 2012a \\
\hline & & Meditación bribri & Contrabajo & $\mathrm{s} / \mathrm{d}$ & $\begin{array}{l}\text { Premio Nacional de Música } \\
\text { "Siete Provincias" }\end{array}$ & Vicente, 2012 \\
\hline & & Meditación Bribri & Contrabajo & 1984 & $\begin{array}{l}\text { Premio Nacional de las Artes } \\
\text { Siete Provincias }\end{array}$ & Camacho, 2012a \\
\hline & & Lamento bribri & Soprano, flauta, dos guitarras y violonchelo & $\mathrm{s} / \mathrm{d}$ & $\mathrm{s} / \mathrm{d}$ & Chatski, 2012a \\
\hline & & Lamentos Bribris & Soprano, flauta traversa, chelo y dos guitarras & $\mathrm{s} / \mathrm{d}$ & s/d & Camacho, 2012a \\
\hline & & Antonio & Piano a cuatro manos & 1987 & $\mathrm{~s} / \mathrm{d}$ & Camacho, 2012a \\
\hline & & Chamánicos & $\mathrm{s} / \mathrm{d}$ & $\mathrm{s} / \mathrm{d}$ & $\mathrm{s} / \mathrm{d}$ & Chatski, 2012a \\
\hline & & Chamánicos - Ritual, no. 1 & Piano a cuatro manos & $s / d$ & $\mathrm{~s} / \mathrm{d}$ & Vicente, 2012 \\
\hline & & Chamánicos & Piano a cuatro manos & 2000 & $s / d$ & Camacho, $2012^{a}$ \\
\hline & & Chamánicos & $\mathrm{s} / \mathrm{d}$ & 2002 & $\mathrm{~s} / \mathrm{d}$ & Campos, 2014 \\
\hline & & Misa indígena & Música vocal & $s / d$ & $\mathrm{~s} / \mathrm{d}$ & Vicente, 2012 \\
\hline & & Segunda sinfonía Humanidades & Soprano, coro y orquesta sinfónica. & 2007 & $\begin{array}{l}\text { Premio Nacional Aquileo J. } \\
\text { Echeverría }\end{array}$ & Camacho, 2012a \\
\hline & & Siete Haikus & Piano & 2010 & $\mathrm{~s} / \mathrm{d}$ & Chatski, 2012a \\
\hline & & Siete Haikus & Piano & 2020 & $\mathrm{~s} / \mathrm{d}$ & Camacho, 2012a \\
\hline & & Los Siete Haikus & Piano & 2012 & $\mathrm{~s} / \mathrm{d}$ & Campos, 2014 \\
\hline & & Juego \# 3 de cuentos y leyendas & Quinteto de maderas, bombo y narrador. & 2012 & $\mathrm{~s} / \mathrm{d}$ & Camacho, 2012a \\
\hline & & Las memorias de Sibö & Quinteto de maderas y narrador & 2015 & $s / d$ & Campos, 2015 \\
\hline
\end{tabular}

Fuente: Elaboración propia 